\title{
The Synthesis of Heat-shock Proteins after a Decrease in Translational Capacity in Escherichia coli
}

\author{
By JOACHIM SCHNIER† \\ Max-Planck-Institut für Molekulare Genetik, Abt. Wittmann, Ihnestr. 73, \\ D-1000 Berlin 33, FRG
}

(Received 13 April 1987; revised 8 July 1987)

\begin{abstract}
Various conditions which decrease translational capacity and enhance the synthesis of ribosomal components were analysed with respect to the synthesis of heat-shock proteins in Escherichia coli: (a) deprivation of streptomycin from a streptomycin-dependent mutant, $(b)$ addition of tetracycline to a partially tetracycline-resistant strain, and (c) nutritional shift-up conditions. In all cases, the rate of synthesis of the heat-shock proteins DnaK, GroEL and C62.5 decreased while the synthesis of ribosomal components increased. Thus inhibition of ribosome formation or a decrease in translational capacity do not induce the stress proteins, but have the opposite effect.
\end{abstract}

\section{INTRODUCTION}

A number of reports describe a set of proteins induced after a heat-shock in prokaryotic and eukaryotic organisms (for a review see Neidhardt et al., 1984). These proteins are termed heatshock proteins. At elevated temperatures synthesis of some of them was dependent on a sigmafactor-like protein whose genetic locus was designated htpR (Yura et al., 1984). Mutations in this gene result in temperature-sensitive growth (Yamamori \& Yura, 1982), the inability to induce certain heat-shock proteins (Neidhardt \& VanBogelen, 1981) and an impairment in the degradation of proteins (Goff et al., 1984).

$h t p R$-dependent heat-shock proteins are generally induced after subjecting cells to different kinds of stress conditions, e.g. infection with phage $\lambda$ (Drahos \& Hendrix, 1982), UV-irradiation (Krueger \& Walker, 1984), addition of ethanol (Travers \& Mace, 1982), nalidixic acid (Krueger $\&$ Walker, 1984), puromycin and amino acid analogues and the expression of certain abnormal proteins in a cell (Goff \& Goldberg, 1985). Although it was proposed that mistranslated polypeptide products as well as other abnormal proteins cause the induction of heat-shock proteins (Goff \& Goldberg, 1985), the molecular mechanism of the induction is not yet understood. Abnormal proteins might play the key role in stress induction in eukaryotes as well. It has been proposed that the level of ubiquitin, a small protein involved in protein degradation, becomes a limiting factor during a stress so that the inactivation by ubiquitin of a factor necessary for the synthesis of heat-shock proteins does not occur (Munro \& Pelham, 1985). Another triggering signal to induce a stress response might be small nucleotide compounds, since they are synthesized after various kinds of oxidation stress (Bochner et al., 1984). Other mechanisms also seem to be involved. Recently, $h t p R$-independent but relA-dependent heatshock protein synthesis was observed after amino acid starvation (Grossmann et al., 1985).

Because many natural stress conditions influence the synthesis of proteins belonging to the transcriptional and translational machinery (Lemaux et al., 1978; Zengel \& Lindahl, 1985), it is

$\dagger$ Present address: Department of Microbiology and Immunology, University of California, Berkeley, CA 94720, USA.

Abbreviation : $\alpha$-MG, methyl $\alpha$-D-glucoside. 
important to investigate the modulation of heat-shock protein synthesis under conditions which affect translation in a cell. This paper describes conditions which impair translation and are known to partly enhance the synthesis of ribosomal components. A relationship between translational impairments and the regulation of heat-shock protein synthesis is discussed.

\section{METHODS}

Bacterial strains and culture conditions. The bacterial strains are listed in Table 1. Cells were grown in minimal A medium (Davis \& Mingioli, 1950) supplied with glucose ( $0.4 \%$ or $0.2 \%$ when methyl $\alpha$-D-glucoside was used). All amino acids were added in a final concentration of $25 \mu \mathrm{g} \mathrm{ml}^{-1}$. Antibiotics were added to final concentrations of $250 \mu \mathrm{g} \mathrm{ml}^{-1}$ for streptomycin and $1 \mu \mathrm{g} \mathrm{ml}^{-1}$ for tetracycline. Some of the experimental conditions are given in the legends to the figures.

Analytical techniques. Two-dimensional gel electrophoresis was done according to O'Farrell (1975) with $1 \mathrm{~mm}$ gel thickness and a $\mathrm{pH}$ range from 5 to 7 . The spots were identified according to the gene-protein index (Neidhardt et al., 1983).

Labelling experiments. Cells were grown to an $\mathrm{OD}_{650}$ of about $0.15-0.2$ before any treatments were performed. A sample ( $1 \mathrm{ml}$ ) was labelled with $20 \mu \mathrm{Ci}\left[{ }^{35} \mathrm{~S}\right]$ methionine (Amersham; $800 \mathrm{Ci} \mathrm{mmol}^{-1}$ ) for $1 \mathrm{~min}$ (in the case of strain $\mathrm{N} 543$ for $10 \mathrm{~min})$ and then chased with excess unlabelled methionine for another $2 \mathrm{~min}$. This culture $(0.5 \mathrm{ml})$ was mixed with $1 \mathrm{ml}$ of a culture grown in the presence of $40 \mu \mathrm{Ci}\left[{ }^{3} \mathrm{H}\right.$ ]alanine (Amersham; $54 \mathrm{Ci} \mathrm{mmol}^{-1}, 2.0 \mathrm{TBq}$ $\mathrm{mmol}^{-1}$ ) for several generations. Growth was stopped by chilling the cells in ice. The cells were harvested by centrifugation and prepared for electrophoresis as described by O'Farrell (1975).

For the determination of the relative synthesis rate, spots were cut out from gels and dissolved in a solution containing 3\% Protosol (NEN) in Econofluor (NEN) overnight at $37^{\circ} \mathrm{C}$. The vials were then kept at room temperature for several hours and radioactivity was determined in a Beckman scintillation counter (model LS 7000). The relative rate of synthesis of individual proteins was calculated in the following way. The ratio $A_{0}=$ $\left({ }^{35} \mathrm{~S} /{ }^{3} \mathrm{H}_{\text {protein }}\right) /\left({ }^{35} \mathrm{~S} /{ }^{3} \mathrm{H}_{\text {total }}\right)$ for the differential rate of synthesis at time 0 before any treatment of cells was adjusted to 1.0 . The other values $\left(A_{\mathrm{i}}\right)$ were normalized to $A_{0}$ by the $A_{\mathrm{i}} / A_{0}$ ratio. For the experiment with tetracycline, a protein (dihydrolipoamide acetyltransferase) whose synthesis did not change after the treatment of cells was used as a standard. For autoradiography, gels were dried and exposed to X-ray film (Fuji) for 1-2 d.

\section{RESULTS}

\section{The streptomycin-dependent strain N543}

Partially or strictly streptomycin-dependent strains show an increase in the synthesis rate of all ribosomal proteins and RNA after deprivation of the drug (Zengel et al., 1977; Hummel \& Böck, 1983). At the same time, there is inhibition of ribosome assembly and a slower elongation rate during polypeptide synthesis. Therefore, I investigated whether there is a difference in the synthesis of heat-shock proteins after deprivation of streptomycin from a dependent strain.

Extracts of pulse-labelled cells were prepared from strain N543, a strictly streptomycindependent strain, and proteins separated by two-dimensional gel electrophoresis (Fig. 1). From the intensities of the pulse-labelled protein spots in the autoradiographs it is obvious that some proteins, including some of the abundant heat-shock proteins like DnaK, GroEL and C62.5 (arrows), showed a decreased synthesis in the absence of streptomycin. There are also proteins whose synthesis was not or was hardly affected, e.g. the ATPase $\beta$-subunit (Fig. $1 a$, circle). A heat-shock experiment was performed with the culture lacking streptomycin. The synthesis of heat-shock proteins was stimulated (Fig. 1c), to a level similar to the basal level of the culture grown in the presence of streptomycin, indicating that the heat-shock response itself was not impaired. In the absence of streptomycin the differential rate of synthesis for DnaK 15 min after a heat-shock to $42^{\circ} \mathrm{C}$ was 3.7 compared to 9.5 in the presence of streptomycin; that for GroEL was 4.78 compared to 18.6 .

The relative synthesis rates of ribosomal proteins S1, L7/12 and EF-G, and heat-shock proteins DnaK and GroEL, are shown in Fig. 2. Due to the similar regulation of all ribosomal proteins as one class and heat-shock proteins as another class, these proteins can be taken as representative of all other proteins from the same classes. One hour after deprivation of streptomycin the synthesis rate of heat-shock proteins DnaK and GroEL had already decreased, but it then remained constant up to $4 \mathrm{~h}$ (Fig. 2). The synthesis rate of the ribosomal proteins 
Table 1. Strains and plasmids used

\begin{tabular}{|c|c|c|}
\hline Strain & Characteristics & Source \\
\hline CP78 & $\mathrm{F}_{\lambda^{-}}^{-}$thi thrl leu6 his65 argE or B46 gal3 xyl7 malA1 mtl 2 aral3 tonA 2 supE44 & A. Böck \\
\hline N543 & $\mathrm{F}^{-}$thi argE3 his4 ilv158 proA2 lacY1 xyl galK2 $\mathrm{Str}^{\mathrm{d}}$ & H. G. Wittmann \\
\hline CB877 & $\begin{array}{l}\mathrm{F}^{-} \text {lacZ thi galK phoA8 recA56 rpsL; Tn } 10 \text { at undefined position; contains } \\
\text { two plasmids, pCB154 (mini-F, Kan }{ }^{\mathrm{r}} \text {, tet-repressor gene under control of } \\
\text { lacPO) and pCB250 (pKO-1 derivative with lacZ and phoA under control } \\
\text { of } t \text { tet-promoters) }\end{array}$ & C. Beck \\
\hline
\end{tabular}
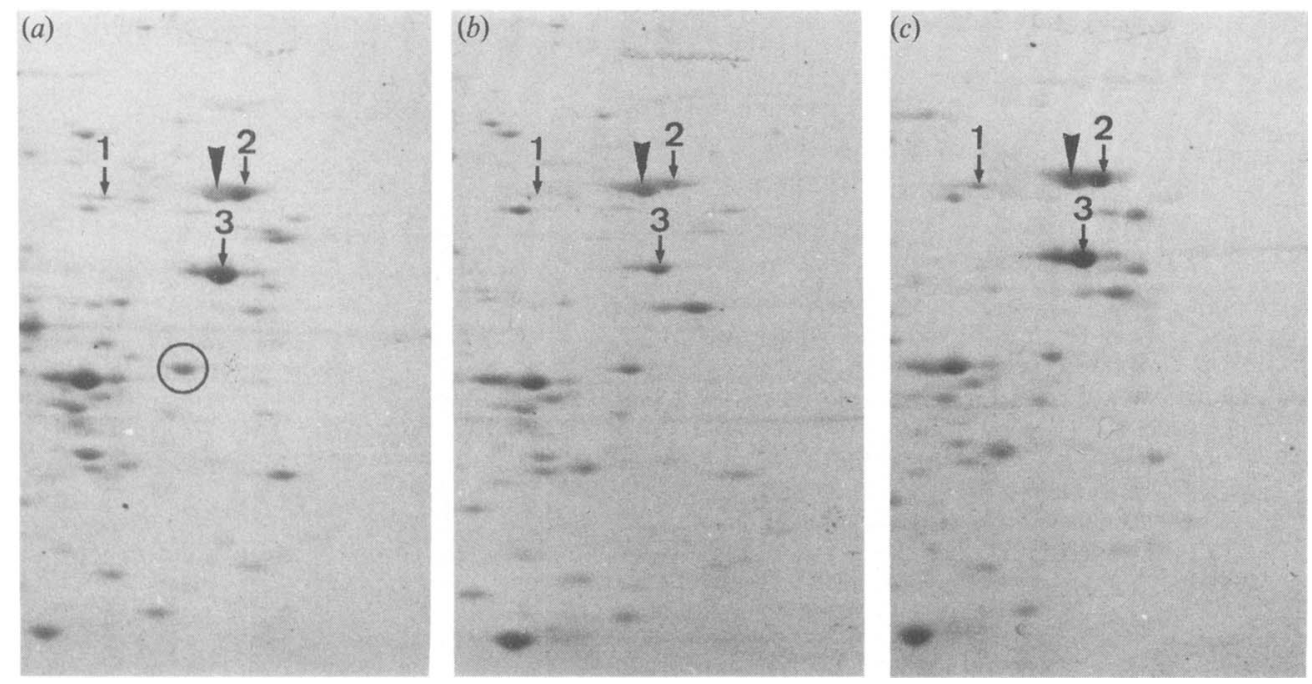

Fig. 1. Autoradiographs of parts of two-dimensional gels after deprivation of streptomycin from strain N543. (a) Strain N543 was grown in the presence of streptomycin at $37^{\circ} \mathrm{C} ;(b)$ the same strain was incubated for $4 \mathrm{~h}$ in the absence of streptomycin; $(c)$ the culture from $(b)$ was shifted to $42{ }^{\circ} \mathrm{C}$ and labelled $10 \mathrm{~min}$ later. Cells were pulse-labelled with $\left[{ }^{35} \mathrm{~S}\right] \mathrm{methionine.} \mathrm{The} \mathrm{arrowhead} \mathrm{points} \mathrm{to}$ ribosomal protein S1 and the arrows to proteins C62.5 (1), DnaK (2) and GroEL (3). The circle shows the position of the ATPase $\beta$-subunit. The positions of the spots were identified according to Neidhardt et al. (1983). For more experimental details see legend to Fig. 2.

increased in the absence of streptomycin (Fig. 2). A control culture with streptomycin did not show a significant alteration of the synthesis rate of any of these proteins during the same time period (data not shown).

\section{Effect of tetracycline on strain CB877}

In order to confirm the correlation described above, the effect of impaired translation by other inhibitors of protein synthesis was studied. However, it is difficult to analyse the action of inhibitors on protein synthesis in vivo because the antibiotics block translation very rapidly, making it almost impossible to analyse newly synthesized polypeptides. In order to overcome this difficulty the following system for tetracycline was used (C. Beck, personal communication). A strain (CB877) which had transposon Tn10 inserted at an unknown position in the chromosome was transformed with two different kinds of plasmids. One plasmid, pCB154, had the tet-repressor gene under the control of the lacPO promoter. Therefore, any gene expression from the tet-promoters on Tn10 was repressed and cells became partially sensitive to tetracycline. Addition of the antibiotic inactivated the repressor, and transcription from the tetpromoters could be initiated, conferring resistance after a lag period. During this lag period, 


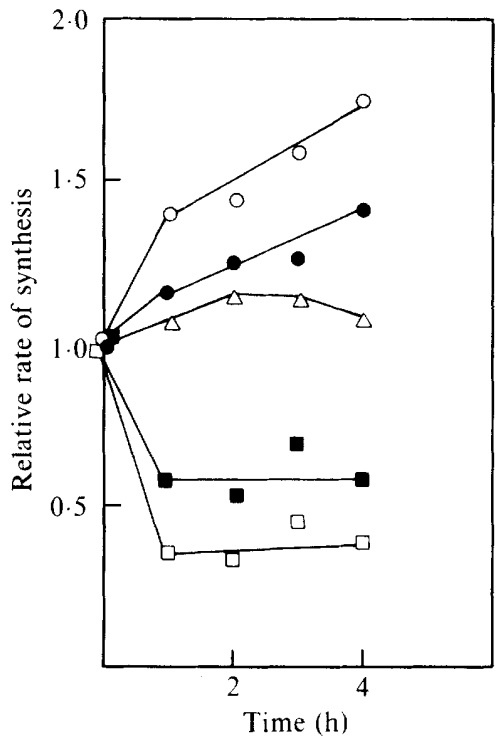

Fig. 2. Relative rates of synthesis of individual proteins after deprivation of streptomycin from strain N543. Cells were grown at $37^{\circ} \mathrm{C}$ in minimal A medium supplied with glucose and amino acids. When the culture reached an $\mathrm{OD}_{650}$ of approximately $0 \cdot 2$, cells were filtered through a prewarmed Millipore filter and washed with fresh prewarmed culture medium lacking streptomycin. Then the cells were resuspended in this medium and the culture was divided. To one culture streptomycin was added. After $15 \mathrm{~min}$ the first sample of both cultures was withdrawn and pulse-labelled. Since there was no difference in the rate of protein synthesis between the samples from the two cultures this value was taken as the reference. At $1 \mathrm{~h}$ intervals samples were withdrawn from both cultures and labelled. $\square$, GroEL; $\mathbf{\square}$, DnaK; $\triangle, \mathrm{S} 1 ; \mathrm{O}, \mathrm{EF}-\mathrm{G} ; \mathbf{O}, \mathrm{L} 7 / 12$.

cells were transiently sensitive to the drug. The activation of the tet-promoters could be monitored by the other plasmid, pCB250. This plasmid contained the tet-promoters fused to pho $A$, the gene for alkaline phosphatase, and to the lac $Z$ gene for $\beta$-galactosidase.

Concentrations of tetracycline higher than $1 \mu \mathrm{g} \mathrm{ml}^{-1}$ significantly inhibited the incorporation of $\left[{ }^{35} \mathrm{~S}\right]$ methionine, so the experiments were performed with a final concentration of $1 \mu \mathrm{g} \mathrm{ml}^{-1}$. Tetracycline was added to a culture of CB877 grown at $37^{\circ} \mathrm{C}$ and after different times (for the autoradiograph after $10 \mathrm{~min}$ ) of incubation cells were pulse-labelled and proteins from cell extracts separated by two-dimensional gel electrophoresis (Figs 3 and 4). The activation of the tet-promoters could be visualized by the induced synthesis of $\beta$-galactosidase (protein 1, Fig. 3 ) and alkaline phosphase (protein 2, Fig. 3). Further, there was a marked increase in synthesis of ribosomal proteins and factors like S1, S6, L9, L7/12 and EF-G (arrows) after the addition of tetracycline; the increase was estimated to be about twofold for S1 and EF-G (Fig. 4). Concomitantly, there was a decrease in the synthesis of several proteins including the heatshock proteins GroES/L, DnaK, F84. 1, C62.5 and Lon (arrowed). It should, however, be noted that the synthesis of a number of non-ribosomal or non-heat-shock proteins was unaffected or minimally affected by the treatment. Two of these are dihydrolipoamide acetyltransferase and the ATPase $\beta$-subunit (Fig. $3 a$, circle, and Fig. 4). Prolonged incubation of the culture restored the original synthesis rate of ribosomal and heat-shock proteins as judged by autoradiographs (data not shown) and as shown in Fig. 4.

\section{Effect of nutritional shifts}

It was of interest to determine the modulation of heat-shock protein synthesis, when the translational capacity was altered by natural conditions such as nutritional shifts. This was achieved by an initial carbon starvation with methyl $\alpha$-D-glucoside $(\alpha-M G)$ followed by readdition of glucose and/or amino acids. $\alpha-\mathrm{MG}$ is a competitive inhibitor for glucose (Kessler \& 

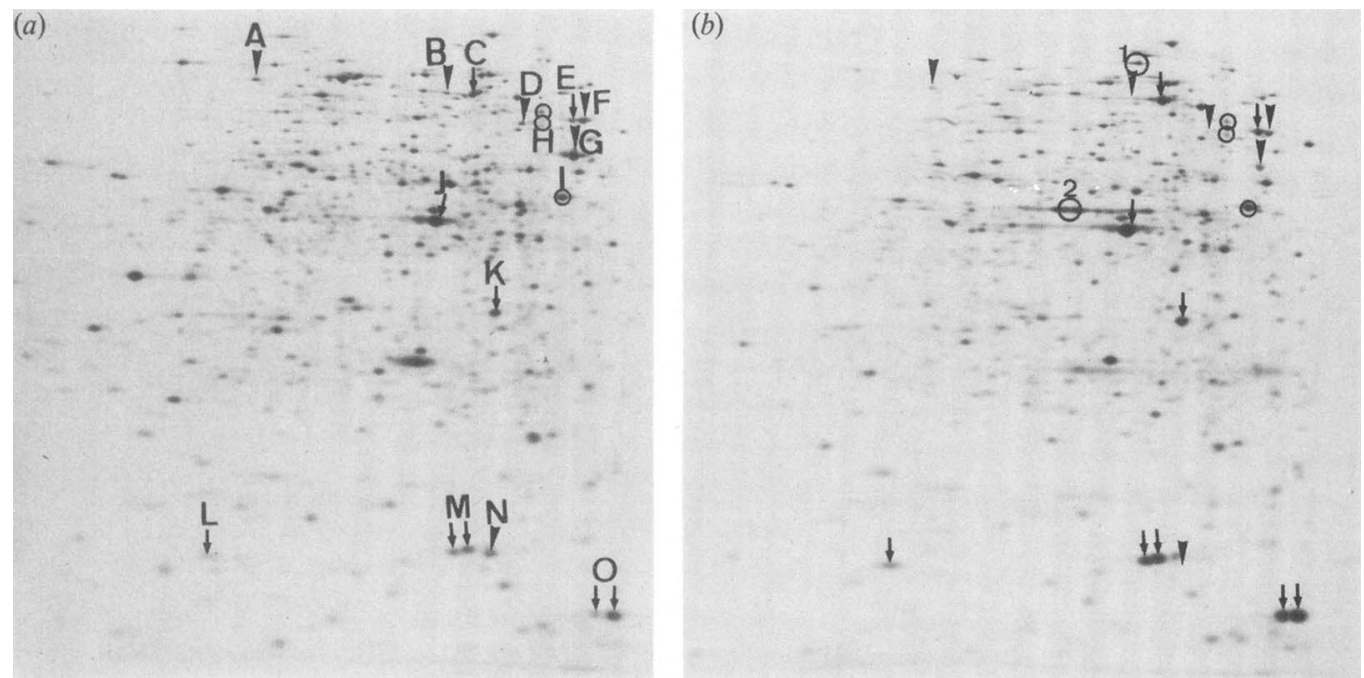

Fig. 3. Autoradiographs of two-dimensional gels after addition of tetracycline to strain CB877. (a) Sample from strain CB877 grown in the absence of tetracycline; $(b)$ sample taken 10 min after the addition of tetracycline $\left(1 \mu \mathrm{g} \mathrm{ml}^{-1}\right)$ to the culture from $(a)$. Cells were pulse-labelled as described. The arrows point to ribosomal components and arrowheads to some heat-shock proteins. Circle 1 shows the position of $\beta$-galactosidase and circle 2 that of alkaline phosphatase according to Neidhardt et al. (1983). The following proteins were identified: A, Lon protease; B, F84.1; C, EF-G; D, C62.5; E, S1; F, DnaK; G, GroEL; H, dihydrolipoamide acetyltransferase; I, ATPase $\beta$-subunit; J, EF-Tu; K, EF-Ts; L, L9; M, S6 A and B form; N, GroES; O, L7/12.

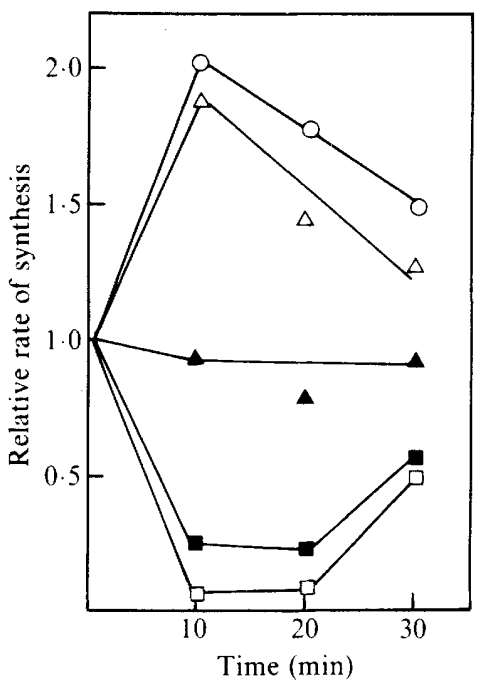

Fig. 4. Relative rates of synthesis of individual proteins after the addition of tetracycline to strain $\mathrm{CB} 877$. When the culture reached an $\mathrm{OD}_{650}$ of 0.2 a sample was removed for labelling as described. Tetracycline $\left(1 \mu \mathrm{g} \mathrm{ml}^{-1}\right)$ was added to the rest of the culture and samples were removed for labelling at the indicated times. In this experiment dihydrolipoamide acetyltransferase was used as a standard, since the synthesis of this protein was not affected and resembled total protein synthesis. $\square$, GroEL; $\boldsymbol{\square}$, DnaK; $\Delta$, ATPase $\beta$-subunit; $\triangle$, ribosomal protein $\mathrm{S} 1$; $\mathrm{O}$, EF-G. 


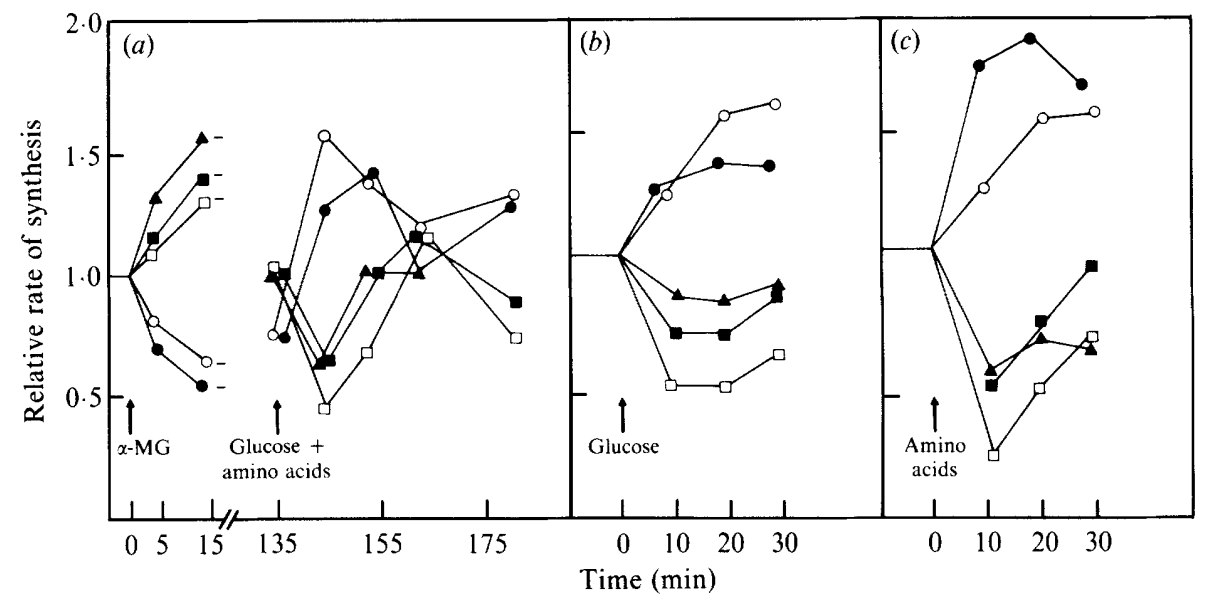

Fig. 5. Relative rate of synthesis of individual proteins after nutritional shifts of strain CP78. Strain CP78 was grown in minimal A medium supplied with $0.2 \%$ glucose. At an $\mathrm{OD}_{650}$ of about 0.2 a 10 -fold excess of $\alpha$-MG was added $(a)$. After one more generation glucose and amino acids $(a)$, or glucose $(b)$, or amino acids $(c)$, were added. The relative rate of synthesis was determined. The value obtained before the addition of $\alpha-\mathrm{MG}$ was taken as the reference. $\square$, GroEL; $\boldsymbol{\square}, \mathrm{DnaK} ; \boldsymbol{\Delta}, \mathrm{C} 62.5 ; \boldsymbol{O}, \mathrm{L} 7 / 12$; O, EF-G.
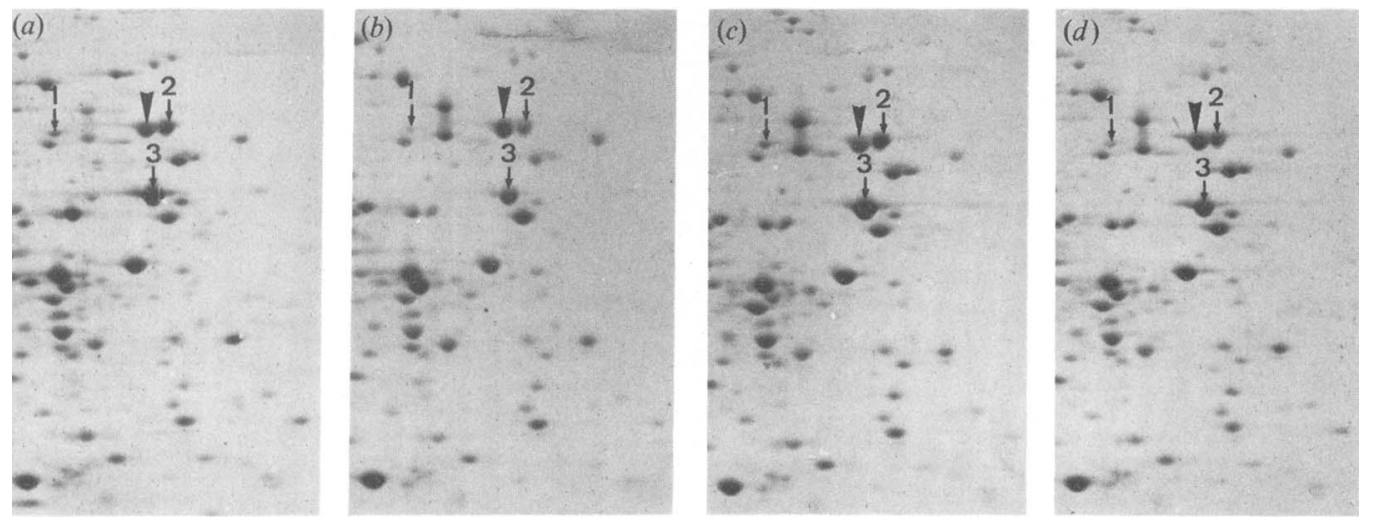

Fig. 6. Autoradiographs of parts of two-dimensional gels after nutritional shift-up of strain CP78. The experimental procedures were basically as described for Fig. $5(a)$. Cells were labelled with $\left[{ }^{35} \mathrm{~S}\right]-$ methionine and proteins separated by two-dimensional gel electrophoresis. The arrowhead points to ribosomal protein S1 and the arrows to proteins C62.5 (1), DnaK (2) and GroEL (3). (a) Before the addition of glucose and amino acids; $(b) 10 \mathrm{~min},(c) 30 \mathrm{~min}$ and $(d) 50 \mathrm{~min}$ after the addition of glucose and amino acids.

Rickenberg, 1963) and is transported into the cell but cannot be futher metabolized. Its effect on protein and RNA synthesis as well as the involvement of small nucleotide compounds have been investigated (Hansen et al., 1975).

Strain CP78 was grown in minimal A medium supplied with glucose and the required amino acids. $\alpha$-MG was added to the culture in a 10 -fold excess over glucose, and the relative rate of synthesis of the same heat-shock proteins and ribosomal components was measured as in previous experiments (Fig. $5 a$ ). As expected, the synthesis rate of the ribosomal components L7/12 and EF-G decreased and then stayed lower, even after one further generation of growth. On the other hand, heat-shock protein synthesis (DnaK, GroEL, C62.5) transiently increased about $1 \cdot 5$-fold over about $30 \mathrm{~min}$ and then returned to the original rate. 
One generation after the addition of $\alpha-\mathrm{MG}$, glucose (at the same concentration as $\alpha-\mathrm{MG}$ ), and/or an amino acid mixture (final concentration $25 \mu \mathrm{g} \mathrm{ml}^{-1}$ of each amino acid, except methionine and alanine) were supplied to the culture. Within $10 \mathrm{~min}$ the synthesis of the ribosomal components increased (Fig. $5 a$; Fig. $6 a, b$ ). At the same time, the heat-shock proteins showed a transient decrease in synthesis over a 30 min period. As can be seen in Fig. 6 , mainly the synthesis of heat-shock proteins (C62.5, DnaK, GroEL) and ribosomal proteins (for example protein $\mathrm{S} 1$ ) was affected. The results in Figs 5 and 6 indicate an inverse relationship in the synthesis of these two classes of proteins.

In order to see whether the observed effect was caused by the specific nutrients, the experiment was repeated with either glucose or amino acids added separately. A similar result was obtained, namely a transient decrease in the synthesis of the three heat-shock proteins (Fig. $5 b, c)$. The decrease could thus be caused independently by both glucose and amino acids. Interestingly, the lower synthesis rate seemed to last only during the accelerated ribosome synthesis. When the ribosome synthesis had reached a new stable higher level, the heat-shock protein synthesis was also restored to nearly the original level. The decrease in heat-shock protein synthesis was apparently due to the shift-up condition rather than to a specific effect of the nutrients added.

\section{DISCUSSION}

In the present work a number of conditions were investigated which affected translation. A correlation was found that when ribosome synthesis was increased, the synthesis of heat-shock proteins was decreased. Lemaux et al. (1978) also reported an increase in ribosomal protein and a decrease in heat-shock protein synthesis after a temperature shift from $36^{\circ} \mathrm{C}$ to $28^{\circ} \mathrm{C}$. Similarly, Grossmann et al. (1985) found a decrease of heat-shock protein synthesis after amino acid starvation of a relA strain, a condition under which the synthesis rate of ribosomal components is unaltered or even stimulated. Recently, plasmids were constructed containing fragments of the rpsA gene for ribosomal protein S1 (Schnier et al., 1986). Although one fragment led to a strong induction of heat-shock proteins due to an abnormal polypeptide residue, another fragment, which was toxic for the cells, led to a decreased heat-shock protein synthesis and an increase in ribosomal components (author's unpublished results).

The mechanism of modulation of heat-shock protein synthesis during the increase in the synthesis of ribosomal components remains to be elucidated. The various autoradiographs have revealed that, although the synthesis of heat-shock proteins and also of some other proteins was affected, the synthesis of many other proteins remained unaltered. This was also confirmed by directly using the synthesis rate of one such protein as a standard instead of total protein synthesis (Fig. 4, dihydrolipoamide acetyltransferase or ATPase $\beta$-subunit). The decreased synthesis is not a consequence of a general reduction in protein synthesis due to the increased ribosome synthesis. As a possible mechanism one could postulate the stringent regulation which affects the synthesis of many proteins (Reeh et al., 1976). Recently, it was shown that heat-shock proteins are stringently regulated and that their synthesis increased when ribosome biogenesis was inhibited (Grossmann et al., 1985).

The results would suggest that certain types of proteins, including heat-shock proteins, which are not needed or may even disturb accelerated ribosome formation are specifically synthesized in reduced amounts. We have genetic evidence for the involvement of one heat-shock protein in the turnover of ribosomal protein L24, an initiator protein for the assembly of 50 S ribosomes. A mutation leading to temperature-sensitive growth was localized in the structural gene for ribosomal protein L24 (Nishi \& Schnier, 1986). We isolated a spontaneous temperatureresistant suppressor mutant and identified a mutation in the lon gene for protease LA. Protein L24 and some other $50 \mathrm{~S}$ ribosomal proteins, belonging to an assembly precursor, are more slowly degraded in the lon mutant (K. Nishi \& J. Schnier, unpublished results). It might be that during ribosome biogenesis an increased level of the Lon protease causes some degradation of assembly precursors.

In summary, conditions which stimulate ribosome formation cause a decrease in heat-shock protein synthesis. Therefore, accelerated ribosome synthesis even under lethal conditions, such 
as the deprivation of a drug from a drug-dependent strain, reflects a situation in the cell which is opposite to stress situations known to induce heat-shock protein synthesis.

I thank Dr H. G. Wittmann for support. Further, I thank Dr C. Beck for strain CB877 and S. E. Behrens for some technical assistance. I also thank $\mathrm{Dr} \mathrm{K}$. Nishi for critically reading the manuscript.

\section{REFERENCES}

BoChNer, B. R., LeE, P. C., Wilson, S. W., Cutler, C. W. \& Ames, B. N. (1984). AppppA and related adenylated nucleotides are synthesized as a consequence of oxidation stress. Cell 37, 225-232.

Davis, B. D. \& Mingioli, E. S. (1950). Mutants of Escherichia coli requiring methionine or vitamin B12. Journal of Bacteriology 60, 17-28.

DRaHos, D. J. \& HendRIX, R. W. (1982). Effect of bacteriophage lambda infection on the synthesis of groE protein and other Escherichia coli proteins. Journal of Bacteriology 149, 1050-1063.

GofF, S. A. \& GoldberG, A. L. (1985). Production of abnormal proteins in Escherichia coli stimulates transcription of lon and other heat-shock genes. Cell 41, 587-595.

GofF, S. A., Casson, L. P. \& Goldberg, A. L. (1984). Heat-shock regulatory gene $h t p R$ influences rates of protein degradation and expression of the lon gene in Escherichia coli. Proceedings of the National Academy of Sciences of the United States of America 81, 66476651 .

Grossmann, A. D., Taylor, W. E., Burton, Z. F., Burgess, R. R. \& Gross, C. A. (1985). Stringent response in Escherichia coli induces expression of heat-shock proteins. Journal of Molecular Biology 186, 357-365.

Hansen, M. T., Pato, M. L., Molin, S., Fill, N. P. \& VON MEYENBURG, K. (1975). Simple downshift and resulting lack of correlation between ppGpp pool size and ribonucleic acid accumulation. Journal of Bacteriology 122, 585-591.

Hummel, H. \& Böck, A. (1983). On the basis of aminoglycoside-dependent growth of mutants from E. coli: physiological studies. Molecular and General Genetics 191, 167-175.

Kessler, D. P. \& Rickenberg, H. V. (1963). The competitive inhibition of $\alpha$-methylglucoside uptake in Escherichia coli. Biochemical and Biophysical Research Communications 10, 482-487.

KrUeger, J. H. \& WALKer, G. C. (1984). groEL and dna $K$ genes of Escherichia coli are induced by UV irradiation and nalidixic acid in an $h t p R$-dependent fashion. Proceedings of the National Academy of Sciences of the United States of America 81, 14991503.

Lemaux, P. G., Herendeen, S. L., Bloch, P. L. \& NEIDHARDT, F. C. (1978). Transient rates of synthesis of individual polypeptides in Escherichia coli following temperature shifts. Cell 13, 427-434.

MunRo, S. \& Pelham, H. (1985). What turns on heat shock genes? Nature, London 317, 477-478.

Neidhardt, F. C. \& VanBogelen, R. A. (1981).
Positive regulatory gene for temperature-controlled proteins in Escherichia coli. Biochemical and Biophysical Research Communications 100, 894-900.

Neidhardt, F. C., Vaughn, V., Phillips, T. A. \& BLOCH, P. L. (1983). Gene-protein index of Escherichia coli K-12. Microbiological Reviews 47, 231-284.

Neidhardt, F. C., VanBogelen, R. A. \& Vaughn, V. (1984). The genetics and regulation of heat-shock proteins. Annual Review of Genetics 18, 295-329.

NiSHI, K. \& SCHNIER, J. (1986). A temperaturesensitive mutant in the $r p l X$ gene for ribosomal protein L24 and its suppression by spontaneous mutations in a $23 \mathrm{~S}$ rRNA gene of Escherichia coli. EMBO Journal 5, 1373-1376.

O'Farrell, P. H. (1975). High resolution two-dimensional electrophoresis of proteins. Journal of Biological Chemistry 250, 4007-4021.

Reeh, S., Pedersen, S. \& Friesen, J. D. (1976). Biosynthetic regulation of individual proteins in relA ${ }^{+}$and relA strains of Escherichia coli during amino acid starvation. Molecular and General Genetics 149, 279-289.

SCHNIER, J., Stöffler, G. \& NiSHI, K. (1986). Deletion and insertion mutants in the gene rps $A$ for ribosomal protein S1. Journal of Biological Chemistry 261, 11866-11871.

Travers, A. A. \& Mace, H. A. F. (1982). The heatshock phenomenon in bacteria - a protection against DNA relaxation? In Heat-Shock from Bacteria to Man, pp. 127-130. Edited by M. J. Schlesinger, M. Ashburner \& A. Tissieres. Cold Spring Harbor, NY: Cold Spring Harbor Laboratory.

YAMAMORI, T. \& YURA, T. (1982). Genetic control of heat-shock protein synthesis and its bearing on growth and thermal resistance in Escherichia coli $\mathrm{K}$ 12. Proceedings of the National Academy of Sciences of the United States of America 79, 860-864.

Yura, T., TOBE, T., ITO, K. \& OSAWA, T. (1984). Heatshock regulatory gene (htpR) of Escherichia coli is required for growth at high temperature but is dispensable at low temperature. Proceedings of the National Academy of Sciences of the United States of America 81, 6803-6807.

ZENGEL, J. M. \& LINDAHL, L. (1985). Transcriptional control of the $\mathrm{S} 10$ ribosomal protein operon of Escherichia coli after a shift to higher temperature. Journal of Bacteriology 163, 140-147.

Zengel, J. M., Young, R., DenNIS, P. P. \& Nomura M. (1977). Role of ribosomal protein S12 in peptide chain elongation: analysis of pleiotropic, streptomycin-resistant mutants of Escherichia coli. Journal of Bacteriology 129, 1320-1329. 